\title{
Modelling landscape controls on dissolved organic carbon sources and fluxes to streams
}

\author{
J. J. Dick · D. Tetzlaff · C. Birkel · C. Soulsby
}

Received: 23 May 2014/Accepted: 16 October 2014/Published online: 30 October 2014

(C) The Author(s) 2014. This article is published with open access at Springerlink.com

\begin{abstract}
Catchment dissolved organic carbon (DOC) fluxes are governed by complex interactions, which control biogeochemical processes generating DOC and hydrological connectivity, facilitating transport through the landscape to streams. This paper presents the development of a coupled hydrologicalbiogeochemical model for a northern watershed with organic-rich soils, to simulate daily DOC concentrations. The parsimonious model design allows the relative importance of DOC fluxes from the major landscape units (e.g. hillslopes, groundwater and riparian saturation area) to be determined. The dynamic extent of the saturated riparian zone, which at maximum wetness comprised $40 \%$ of the drainage area, contributed $84 \%$ of DOC to the stream, of which $16 \%$ was derived from the hillslope soils. This shows the disproportional riparian influence on stream water chemistry and the importance of the non-linearity in hydrological connectivity. The temporal connectivity of each of the landscape units was dependent on antecedent moisture conditions, with highly transient connections between the hillslope and valley bottom saturated area, which were entirely disconnected during the driest periods. The groundwater contribution remained constant, but its relative importance
\end{abstract}

J. J. Dick ( $\bowtie) \cdot D$. Tetzlaff · C. Birkel · C. Soulsby

Northern Rivers Institute, School of Geosciences, University of Aberdeen, Aberdeen AB24 3UF, Scotland, UK

e-mail: jonathan.dick@abdn.ac.uk increased during the driest periods. The study emphasises the importance of conceptualising hydrological connectivity and its relation to hydroclimatic factors, as well soil biogeochemical processes, when modelling stream water DOC.

Keywords DOC - Runoff processes - Connectivity · Biogeochemical models - Landscape units - Upland catchments

\section{Introduction}

Dissolved organic carbon (DOC) is an important biogeochemical component of water quality, that serves as a major energy substrate for aquatic ecosystems, (Halbedel et al. 2013; Tank et al. 2010) and also has implications for the quality and potability of drinking water (Karanfil et al. 2008). These issues are particularly important in northern watersheds with significant coverage of organic soils. Consequently, there are both theoretical and practical needs, in such areas, to understand the biogeochemistry in terms of how DOC is generated in the landscape and transported to streams. These fluxes are controlled by a hierarchy of interactions involving hydroclimatic drivers, hydrological connectivity, and complex biogeochemical processes. Essentially, organic matter, in the soil carbon pool, is subject to microbial degradation to release DOC into soil water (Hope et al. 1994). 
This release is strongly dependent on both soil temperature and moisture availability with consequent seasonal differences in periods of high and low DOC production in summer/autumn and winter/spring, respectively (Dawson et al. 2008; Winterdahl et al. 2011a; Peterson and Lajtha 2013). Additionally, water fluxes are of critical importance, and hydrological connection is needed to transport DOC through the landscape and into streams (Boyer et al. 1996; Dawson et al. 2008). DOC is generated across the landscape, but areas with the highest soil carbon density are most important (Dawson et al. 2011). These are often in flatter, low lying areas where histosols can develop, or where other organic rich soils fringe the stream channel as the riparian zone (Billett et al. 2006). The important role of the riparian zone, both in terms of providing a major source of DOC and dynamically mediating hydrological connectivity and DOC fluxes from surrounding hillslopes, has been highlighted in various environments (e.g. McGlynn and McDonnell 2003; Inamdar and Mitchell 2006; Winterdahl et al. 2011b).

Predictive models of watershed DOC transport are important; climate change projections of altered precipitation and temperatures will affect both DOC generation and transport (Laudon et al. 2012; Oni et al. 2014). Such models must therefore capture the dominant hydrological and biogeochemical controls adequately. However, due to the complexity of the biogeochemical processes involved, models that can simulate DOC fluxes tend to be highly parameterised, as best illustrated by the integrated catchment model carbon (INCA-C) (Futter 2007); and TerraFlux (Asner et al. 2001; Neff and Asner 2001). Moreover, within such models hydrological connectivity tends to be treated separately, using independently calibrated models to estimate water delivery (e.g. Band et al. 1991; Futter et al. 2008; Ledesma et al. 2012; Oni et al. 2014; Futter et al. 2014). Other approaches have used simpler models that integrate both the key hydrological and biogeochemical processes to simulate the movement of DOC through soils, to the stream network, an example being the riparian profile flowconcentration integration model (RIM) (Seibert et al. 2009). There are advantages, in terms of parameter identifiability, in using simple catchment models that link the biogeochemistry of DOC generation with hydrological transport processes (Paudel and Jawitz 2012), though existing models are usually restricted to smaller scales (e.g. the soil profile) such as DyDOC and still have a large number of parameters (Michalzik et al. 2003). Recently, Birkel et al. (2014a) developed an approach, that directly coupled a simple conceptualisation of soil biogeochemical processes governing DOC production, with a low parameterised hydrological transport model. This remains a relatively simple (12 parameters in total: 5 hydrological and 7 biogeochemical) process-based approach to simulate DOC generation in catchment landscapes. Despite its simple structure and low parameterisation, it incorporates the major landscape units, captures the non-linear dynamics of the riparian zone and allows spatial disaggregation of DOC generation and transport in different landscape units. Moreover, biogeochemical and hydrological calibration is simultaneous.

An important constraint in many modelling studies is the quality of available data against which to assess simulated dynamics. Up until quite recently, most biogeochemical studies have had relatively coarse weekly or bi-monthly sampling strategies. It is well known that such sampling frequencies, which are often dictated by technical or financial constraints, have limitations in terms of missing crucial short-term information and consequent uncertainties in load estimates. However, high resolution data at daily or sub-daily resolution is becoming increasingly feasible, both technically and financially (Pellerin et al. 2012; Neal et al. 2013). Such data provide a richer resource, which gives more exacting criteria, to challenge biogeochemical models that simulate water quality. In particular, the provision of data at similar timescales to the catchment hydrological response is invaluable for aiding models that seek to simulate hydrologically-mediated water quality parameters, like DOC, where responses are likely to be on daily or sub-daily timescales.

Here, our first main objective was to utilize the aforementioned simple coupled modelling approach of Birkel et al. (2014a), which was initially developed using weekly data to simulate DOC concentrations over an 18 month period, where daily data were available for model assessment. The model is applied in a peat-dominated headwater catchment in the Scottish Highlands, but the generic approach is relevant to other northern regions with organic rich soils, which cover extensive areas in North America and Eurasia. The period coincided with contrasting seasonal extremes and provided both a challenge for 
calibration and a more stringent test for the model. Moreover, the hydrological modelling component was tracer-aided and developed to differentiate the main sources of runoff, their temporal dynamics and hydrological connectivity with the stream channel (Birkel et al. 2010). We therefore had a second objective, to use the model to disaggregate the spatial distribution of DOC fluxes from different landscape units, and assess how their temporal dynamics varied with hydrological connectivity. The wider implications of our findings, in relation to biogeochemical modelling other headwater catchments, are also discussed.

\section{Study area}

The Bruntland Burn (Fig. 1) is a $3.2 \mathrm{~km}^{2}$ catchment in the Scottish Highlands, which has been described elsewhere (Tetzlaff et al. 2007; Birkel et al. 2011a, b). Briefly, elevations range from 248 to 539 meters above sea level, with mean slopes of $13^{\circ}$; the underlying geology is mainly granite in the elevated areas, fringed by associated metamorphic rocks. Below $400 \mathrm{~m}$, the solid geology is covered by various drift deposits (mainly poorly sorted till), which can be up to $40 \mathrm{~m}$ deep in the wide valley bottoms. As with most UK uplands, the Bruntland Burn is a moorland stream; riparian areas are characterised by Sphagnum spp and Molina caerulea dominated blanket peat bog, whilst drier steeper slopes are heather (Calluna vulgaris) dominated (Fig. 1). Forest cover (mainly Scots pine (Pinus sylvestris)) is restricted to small areas on the steeper hillslopes and the riparian zone in the lower catchment.

Organic-rich soils dominate the catchment, with large areas of deep ( $>1 \mathrm{~m})$ peats (Histosols) in valley bottoms and shallow $(<0.5 \mathrm{~m})$ peat on the lower hillslopes, covering $22 \%$ of the catchment. The steeper slopes are characterised by podsols which have a $0.1-0.2 \mathrm{~m}$ deep $\mathrm{O}$ horizon overlying a freely draining mineral sub-soil. The riparian histosols occupy a zone of surface saturation which can be highly dynamic in extent (Fig. 1): ranging between 2 and $40 \%$ of the catchment area, depending upon hydroclimatic and antecedent conditions (Birkel et al. 2010). The stream channel has a low width-depth ratio being narrow $(0.5-1 \mathrm{~m})$ and deep $(0.5-1.5 \mathrm{~m})$ with a limited hyporheic zone. Throughout the stream network there are point source influxes of surface waters, draining the adjacent blanket peat bogs (Fig. 1).

Mean annual precipitation is around $1000 \mathrm{~mm}$, mostly from low intensity frontal events. Mean annual runoff is $700 \mathrm{~mm}$ and potential evapotranspiration $400 \mathrm{~mm}$. Most precipitation events instigate a streamflow response, as water is displaced from the riparian zones as saturation-excess overland flow (Birkel et al. 2010). Runoff coefficients are typically $<10 \%$, but these increase non-linearly in wetter periods to $>40 \%$, as the saturated zone in the valley bottom expands. Such expansion connects lateral flow in the upper horizons of the podzolic soils on the steeper hillslope, to the channel network (Tetzlaff 2014). Mean annual air temperatures are about $6{ }^{\circ} \mathrm{C}$, with daily means ranging between 12 and $1{ }^{\circ} \mathrm{C}$ in summer and winter, respectively.

\section{Data and methods}

Hydrological and biogeochemical data

Daily water samples were collected from the catchment outlet between May 2012 and October 2013, using an ISCO 3700 auto-sampler (Fig. 1). Samples were returned to the laboratory at weekly intervals and analysed for DOC, using a LABTOC Aqueous Carbon Analyser after $0.45 \mu \mathrm{m}$ filtration (Roulet and Moore 2006). Tests, storing samples for a week at summer temperatures, showed changes in DOC concentrations were within measurement error. Samples were acidified using a reagent consisting of $5 \%$ sodium persulphate and $0.5 \%$ orthophosphoric acid diluted in distilled water. Resulting free $\mathrm{CO}_{2}$ was removed using nitrogen, with the remaining fraction converted to $\mathrm{CO}_{2}$ using UV light and measured with infra-red light. For all analyses a top calibration standard of $20 \mathrm{mg}^{-1}$ was used with a 4 point quadratic calibration curve.

In the field, discharge (15 min) was measured at the catchment outlet using an Odyssey capacitance water level logger, at an established gauging point. This was supplemented by meteorological data (air temperature, relative humidity and net radiation) from an automatic weather station $1 \mathrm{~km}$ away, operated by Marine Science Scotland (Malcolm et al. 2008). An altitude-corrected daily precipitation time-series was 


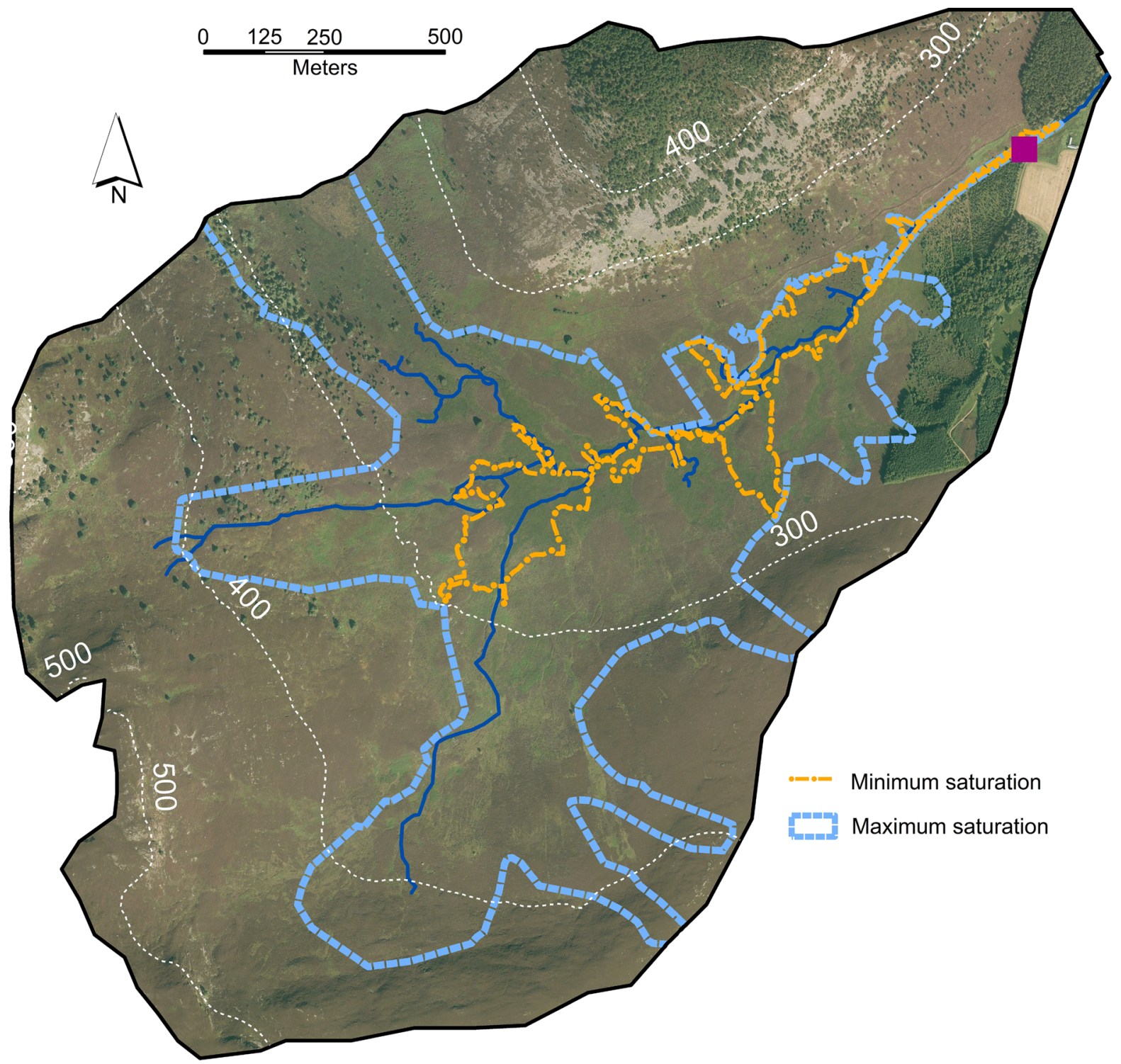

Fig. 1 Topography of the study catchment and location of hydrometric data and DOC sample collection (purple square). Minimum (orange line) and maximum (blue line) saturation extents are included; with vegetation communities reflecting

constructed using an inverse distance elevation gradient interpolation over a $50 \mathrm{~m}$ grid, with coefficients adjusted on a daily basis (Capell et al. 2011). This utilised measurements at five proximate rain gauges (altitudes ranging from 150 to $680 \mathrm{~m}$ ) operated by the Scottish Environmental Protection Agency (SEPA) and the Met Office. One site at Braemar situated $15 \mathrm{~km}$ from the catchment also had daily snow depth data, which we used. Potential evapotranspiration was these saturation extents with green grasses indicating saturated peaty soils and brown heather vegetation is representative of more freely draining podzols. (Color figure online)

estimated using a modified Penman-Monteith equation (Dunn and Mackay 1995).

\section{Modelling approach}

We utilised the coupled hydrological-biogeochemical model, developed by Birkel et al. (2014a) to simulate daily stream flows and DOC concentrations. The model comprises three linked hydrological reservoirs: 
Fig. 2 Conceptual diagram of the coupled hydrologicalDOC model. Blue represents the hydrological processes and red the biogeochemical parameters representing both DOC production terms and loss terms (denoted by L). The biogeochemistry component parameters: $\mathrm{SMD}_{\text {max }}$ is the maximum soil moisture deficit, $\mathrm{kDOC}_{\mathrm{up}}$ and $\mathrm{kDOC}_{\mathrm{sat}}$ are the DOC concentration rate parameter, $\mathrm{E}_{\mathrm{a}}$ is the activation energy, $\mathrm{LQ}_{\mathrm{up}}$, $\mathrm{LQ}_{\text {low }}$, and $\mathrm{LQ}_{\text {sat }}$ are DOC loss parameter). (Color figure online)

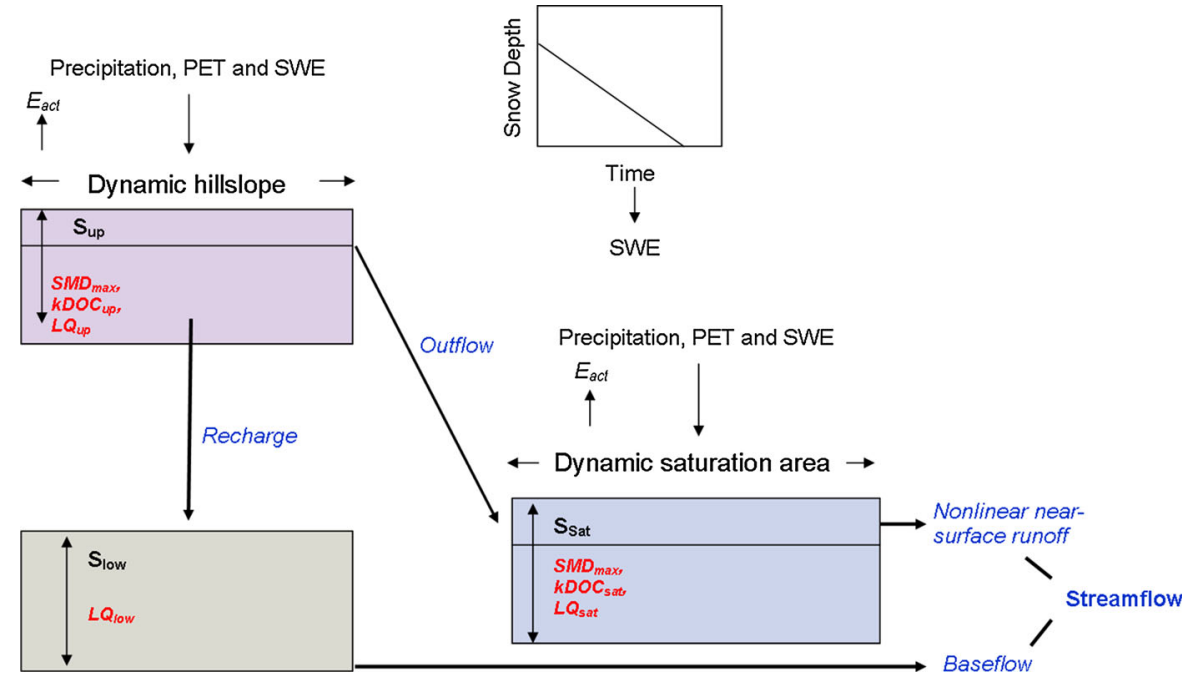

a riparian saturation zone $\left(\mathrm{S}_{\mathrm{sat}}\right)$, upper hillslopes $\left(\mathrm{S}_{\mathrm{up}}\right)$ and groundwater component $S_{\text {low }}$ (Fig. 2). A central feature of the model is that the saturation area is parameterised to expand dynamically in response to precipitation inputs, to generate a non-linear quickflow response, mimicking saturation overland flow primarily from the histosols (Birkel et al. 2010). The model has been used to successfully simulate stream flow, as well as both geochemical and isotopic tracers in the catchment; thus, there is some confidence that it conceptualises runoff generation from the right stores, at the right times, reasonably well (Birkel et al. 2011a, b, 2014a, b). The hydrological model is relatively simple, with just 5 basic parameters (Table 1; Fig. 2): $a$ (which controls hillslope water flux to the saturated area), $b$ (controlling the rate of groundwater discharge), $R e$ (groundwater recharge), $k$ (the water flux rate from saturated area) and $\alpha$ (which conceptualises the non-linear saturation overland flow). Although not part of the original model, a snow melt component was also included, to account for melt water contributions from December 2012 through to April 2013 (Fig. 2). Snow depth data was used from the Met Office site at Braemar to construct a time-related (rather than temperature dependent) snow pack depletion curve and to produce a simple loss relationship, which released melt water into the hillslope and saturated area reservoirs. The snow water equivalent (SWE) was estimated using the depths of snow and the water missing from the measured water balance, to assess the amount of water released.
The biogeochemistry component was implemented to simulate DOC dynamics in the three hydrological stores and transport it along the main runoff pathways to the stream (Birkel et al. 2014a). The biogeochemistry conceptualisation includes two rate parameters $\mathrm{kDOC}\left(\mathrm{d}^{-1}\right)$ for DOC production in the hillslope and riparian zone $\left(k D O C_{u p}\right.$ and $k D O C_{s a t}$ respectively); an energy activation parameter $E_{a}$; ; and a calibrated soil moisture parameter $S M D_{\max }$, below which DOC production stops and the loss parameters (LQ) for groundwater, hillslope, and saturated area $\left(\mathrm{LQ}_{\text {low }}\right.$, $\mathrm{LQ}_{\mathrm{up}}$ and $\mathrm{LQ}_{\mathrm{sat}}$ respectively). Daily DOC concentrations in the stream are flux weighted average values, of the contributing saturation area and groundwater runoff to the total streamflow. Hillslope contributions first drain into the saturation area and, therefore, do not contribute directly to the stream, though the model allows their magnitude to be disaggregated (i.e. estimated directly). The model was conditioned by allowing the water and DOC stores to fill up for 1.5 years (January 2011-May 2012). Initial DOC concentrations were set, based on average concentrations measured using suction cup lysimeters within the peat $\left(\sim 10 \mathrm{mg} \mathrm{l}^{-1}\right.$ at $15 \mathrm{~cm}$ depth, $\sim 30 \mathrm{mg} \mathrm{l}^{-1}$ at $30 \mathrm{~cm}$ depth and $\sim 40 \mathrm{mg} \mathrm{l}^{-1}$ at $50 \mathrm{~cm}$ depth). The average concentration across the three depths was used for the saturated area. For concentrations within the organic horizons of the hillslope, we assumed the concentration, at $15 \mathrm{~cm}$ depth from the saturated area, to be similar to that of the hillslope, due to organic rich content of the hillslope upper soil horizons. 
Table 1 Model parameter values for 2012-2013 (based on daily samples) for the study period compared with the 2007-2009 (based on weekly samples from Birkel et al. 2014a, b)

\begin{tabular}{|c|c|c|c|c|}
\hline Parameter & Units & Initial range & $\begin{array}{l}\text { 2012/13 (daily) } \\
\text { Mean [min, max] }\end{array}$ & $\begin{array}{l}\text { 2007/09 (weekly) } \\
\text { Posterior mean [10th, 90th] }\end{array}$ \\
\hline \multicolumn{5}{|l|}{ Hydrology } \\
\hline $\mathrm{a}$ & $\mathrm{d}^{-1}$ & {$[0.1,0.9]$} & $0.46[0.34,0.56]$ & $0.36[0.14,0.68]$ \\
\hline $\mathrm{b}$ & $\mathrm{d}^{-1}$ & {$[0.001,0.1]$} & $0.003[0.002,0.008]$ & $0.02[0.004,0.05]$ \\
\hline $\operatorname{Re}$ & $\mathrm{d}^{-1}$ & {$[0.1,0.9]$} & $0.79[0.71,0.80]$ & $0.54[0.22,0.84]$ \\
\hline $\mathrm{k}$ & $\mathrm{d}^{-1}$ & {$[0.0001,0.5]$} & $0.09[0.05,0.1]$ & $0.19[0.02,0.42]$ \\
\hline$\alpha$ & - & {$[0.1,0.9]$} & $0.45[0.34,0.69]$ & $0.35[0.08,0.73]$ \\
\hline \multicolumn{5}{|c|}{ Biogeochemistry } \\
\hline $\mathrm{SMD}_{\max }$ & $\mathrm{mm}$ & {$[-200,-1]$} & $-117[-96,-197]$ & $-104[-179,-27]$ \\
\hline $\mathrm{kDOC}_{\mathrm{up}}$ & $\operatorname{mg~} 1^{-1}$ & {$[0,20]$} & $5.74[1.94,6.92]$ & $6.4[1.0,13.8]$ \\
\hline $\mathrm{kDOC}_{\mathrm{sat}}$ & $\operatorname{mg~} 1^{-1}$ & {$[0,20]$} & $1.75[0.06,2.93]$ & $3.5[0.32,8.2]$ \\
\hline $\mathrm{E}_{\mathrm{a}}$ & - & {$[0,20]$} & $1.12[1.0,1.23]$ & $1.13[1.02,1.3]$ \\
\hline $\mathrm{LQ}_{\text {up }}$ & - & {$[0,1]$} & $0.49[0.4,0.7]$ & $0.49[0.09,0.78]$ \\
\hline $\mathrm{LQ}_{\text {low }}$ & - & {$[0,1]$} & $0.17[0.07,0.72]$ & $0.46[0.1,0.88]$ \\
\hline $\mathrm{LQ}_{\mathrm{sat}}$ & - & {$[0,1]$} & $0.09[0.02,0.14]$ & $0.47[0.07,0.89]$ \\
\hline
\end{tabular}

The parameters are as follows: For the hydrology component $(\mathrm{a}=$ hillslope flux parameter, $\mathrm{b}=$ groundwater discharge parameter, $\mathrm{Re}=$ groundwater recharge, $\mathrm{k}=$ non-linear runoff scaling parameter, $\alpha=$ non-linear runoff generation parameter) and for the biogeochemistry component $\left(\mathrm{SMD}_{\max }=\right.$ maximum soil moisture deficit, $\mathrm{kDOC}_{\mathrm{up}}=$ hillslope $\mathrm{DOC}$ concentration rate parameter, $\mathrm{kDOC}_{\mathrm{sat}}=$ saturated area DOC concentration rate parameter, $\mathrm{E}_{\mathrm{a}}=$ activation energy, $\mathrm{LQ}_{\mathrm{up}}=$ hillslope DOC loss parameter, $\mathrm{LQ}_{\text {low }}=$ groundwater DOC loss parameter, $\mathrm{LQ}_{\text {sat }}=$ saturated area DOC loss parameter)

A multi-objective genetic algorithm NSGA2 (Deb et al. 2002) was used for calibration of the model parameters, which simultaneously optimised the modified Kling-Gupta efficiency (KGE) of discharge and stream DOC concentrations. Five hundred parameter populations were sequentially run, over 100 generations, to pool the best parameter mutations. The 500 best parameter sets were subsequently used, to produce simulation ranges as an indication of posterior parameter variability in the absence of a formal uncertainty analysis. The KGE criterion is a three dimensional decomposition of the Nash-Sutcliffe efficiency (NSE) measure and evaluates the dynamics (r), bias (beta) and variability (alpha) on a scale from Inf to 1 , with 1 being a perfect simulation (Gupta et al. 2009; Kling et al. 2012):

$K G E=1-E D$

where:

$E D=\sqrt{[(r-1)]^{2}+[(\alpha-1)]^{2}+[(\beta-1)]^{2}}$

Here, ED is the Euclidian distance from the unknown optimal solution. $r$ is the linear correlation coefficient, alpha the relative variability in the simulated and observed values and $\beta$ is the ratio between the means of the simulated and observed flows.

To test the model, the calibrated parameters from 2012 to 2013 data were applied to a previous DOC data set, sampled weekly between 2007 and 2009 (Dawson et al. 2011). The calibrated parameters from Birkel et al. (2014a) were then used on the 2012-2013 data (Table 2). The aforementioned tests were conducted to assess the robustness of the calibration based on the 2012-2013 data. Reversal of parameter sets (e.g. 2007-2009 parameters) tested the compatibility and quality of the calibration.

\section{Results}

Hydrological and DOC dynamics

During the study the average air temperature was $6.8{ }^{\circ} \mathrm{C}$, with seasonal means of $12.4{ }^{\circ} \mathrm{C}$ during summer (June-September) and $1.2{ }^{\circ} \mathrm{C}$ in winter (December-March). Precipitation in summer 2012 (wettest in 100 years) was high and frequent (Fig. 3a) with 
Table 2 Model performance measures showing the mean, min and max performances (KGE) derived from the best 500 parameter sets for the model calibrated to the 2012-2013 data

\begin{tabular}{|c|c|c|c|}
\hline Model performance & KGE (-) & NSE (-) & $\begin{array}{l}\text { RMSE } \\
\text { (DOC: } \mathrm{mg} \mathrm{l}^{-1} \\
\text { Q: } \mathrm{mm} \mathrm{d}^{-1} \text { ) }\end{array}$ \\
\hline \multicolumn{4}{|l|}{ Q } \\
\hline Mean & 0.64 & 0.48 & 1.33 \\
\hline Min & 0.37 & & \\
\hline Max & 0.66 & & \\
\hline \multicolumn{4}{|l|}{ DOC } \\
\hline Mean & 0.77 & 0.52 & 1.30 \\
\hline Min & 0.33 & & \\
\hline Max & 0.80 & & \\
\hline \multirow{2}{*}{\multicolumn{4}{|c|}{$\begin{array}{l}\text { Model test performance } \\
\text { (Mean 2012-2013 } \\
\text { calibration applied } \\
\text { to } 2007-2009 \text { data) }\end{array}$}} \\
\hline & & & \\
\hline Q & 0.73 & 0.53 & 1.00 \\
\hline DOC & 0.55 & 0.27 & 2.05 \\
\hline \multicolumn{4}{|c|}{ Model test performance } \\
\hline \multicolumn{4}{|l|}{$\begin{array}{l}\text { (Mean 2007-2009 } \\
\text { calibration applied } \\
\text { to 2012-2013 data) }\end{array}$} \\
\hline Q & 0.19 & 0.25 & 1.61 \\
\hline DOC & 0.59 & 0.57 & 1.22 \\
\hline
\end{tabular}

Also includes model test performance for applying the 2012-2013 calibrated parameters to the 2007-2009 data and the calibrated parameters for the 2007-2009 data to the 2012-2013 data. The mean Nash-Sutcliffe Efficiency (NSE) and root mean square error (RMSE) are shown for comparison

$281 \mathrm{~mm}$ over the entire period. Following a dry September, large events occurred in the autumn and early winter. The winter in early 2013 was cold, and significant snow accumulated in January (up to $40 \mathrm{~cm}$ depth), and again in March (up to $14 \mathrm{~cm}$ depth). Thereafter, April and May were wet, but this presaged a dry, warm period in June and July, that was broken by high precipitation in late July. The period between August and October also had below average precipitation. Overall, the summer of 2013 was the driest in 10 years. Stream flows reflected precipitation inputs, with frequent higher flows through summer 2012, with a period of sustained baseflows restricted to September (Fig. 3b). Flows increased through autumn and winter, before a period of low flows coincided with snowpack accumulation in January, and again in March, following melt in February. High flows in April and May coincided with high precipitation events, and then flows dropped in June and July. Despite an increase in response to precipitation in late July, flows continued to fall through August and September, before responding to re-wetting in October.

As expected, measured DOC concentrations showed marked seasonality, with higher summer and low winter concentrations. Within this seasonal pattern, higher DOC peaks coincided with higher flows, though the relationship was markedly nonlinear, with the highest concentrations often linked to smaller discharge events (Fig. 3c). Concentrations were higher in the summer of 2012, compared with 2013, though minimum concentrations each summer coincided with the lowest flows in September 2012 and 2013, respectively. The re-wetting of the catchment in October 2013 saw a late flush of DOC.

\section{Coupled hydrological-biogeochemistry modelling}

The calibrated model gave reasonable simulations for daily DOC and Q over the 16 month period, with the mean KGEs for $\mathrm{DOC}=0.77$ and for $\mathrm{Q}=0.64$, and both means sitting close to the maximum model performance from the 500 retained parameter sets (Table 2). The hydrology component of the model, whilst capturing the overall dynamics quite well, including the snowmelt period, tended to underestimate smaller discharge events following dry periods, notably in the early summer of 2012 and again in 2013. Conversely, following the re-wetting of the catchment in September and October 2014 flows were overpredicted.

The DOC simulations also capture the seasonal and inter-annual dynamics of the study period quite well, including the higher concentrations in summer 2012 compared to 2013. Winter simulations were generally good, though concentrations were under predicted in snowmelt events in early March. Times when the DOC simulations were poorer generally coincided with poorer flow simulations. For example, the underestimation of discharge in the early summers of 2012 and 2013 lead to an underestimation of the initial summer DOC concentrations (Fig. 3c). DOC simulations capture the decline in concentrations in the dry period of September 2012, though are slightly lagged. However, the late July 2013 event and the subsequent decline of concentrations were simulated very well. During autumn 2013, the model underestimated the DOC 
Fig. 3 Daily a Precipitation and snow water equivalent; b measured and simulated discharge on a log-scale; c measured and simulated DOC concentrations.

Simulation ranges represent the 10th/90th percentiles derived from the 500 best parameter sets representing posterior parameter variability. (Color figure online)

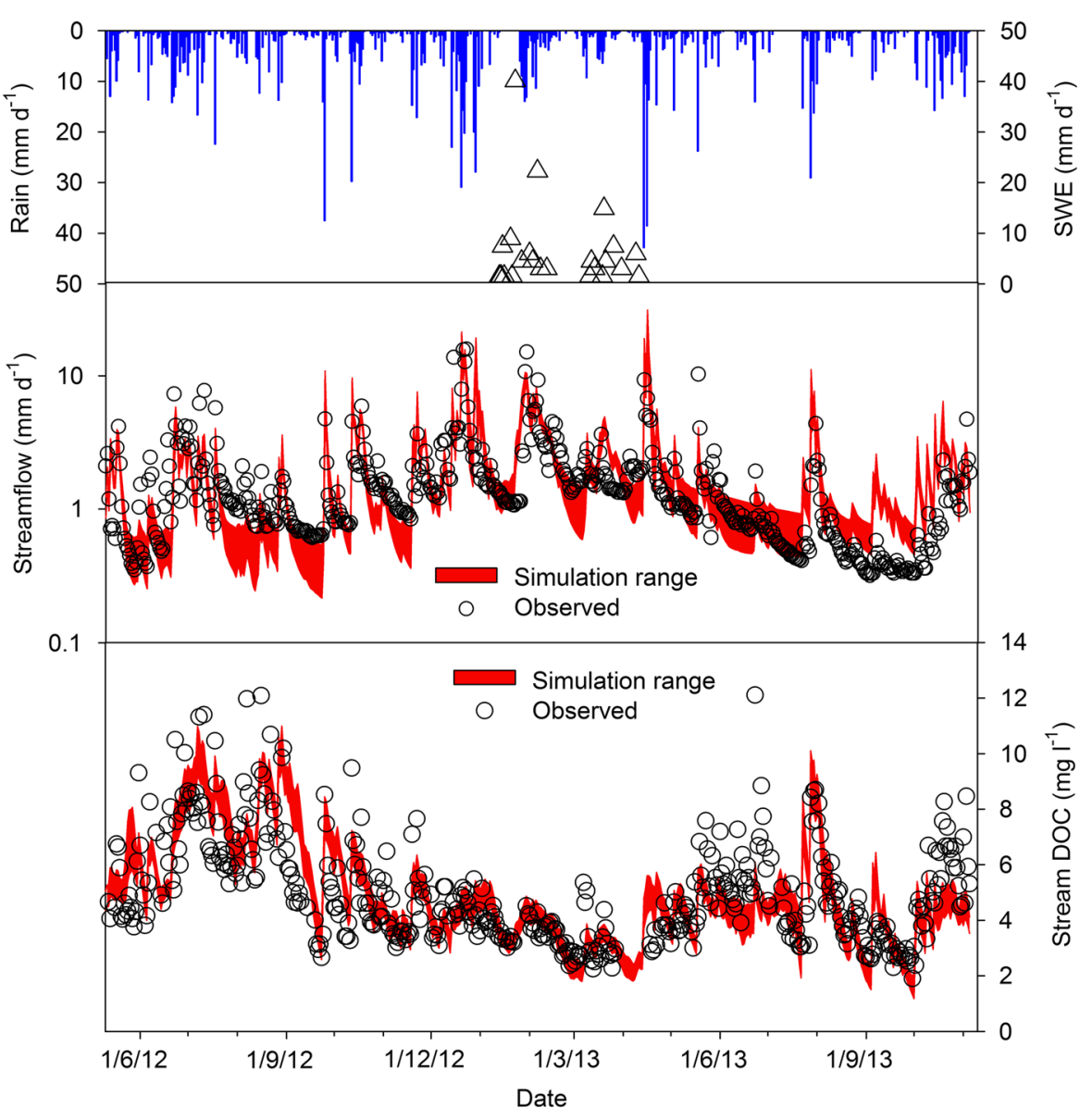

concentrations on re-wetting, probably as a result of flows being over-predicted.

The calibrated model parameters (Table 1) are comparable with those parameters using the weekly measured and simulated 2007-2009 data. Simulations fall within the uncertainty boundaries assessed by Birkel et al. (2014a). Although different methods of calibration were used, the groundwater discharge (b) was lower and groundwater recharge $(R e)$ was higher in 2012-2013, compared to the wetter period 2007-2009. The other parameters were within range of the values defined by the formal uncertainty assessment, for the two study periods. The latter probably reflects the model structure, with less expansion of the saturated area, resulting in less water being routed by overland flow during drier conditions (cf. Birkel et al. 2014a). The biogeochemistry parameters were broadly comparable for both periods, but with lower DOC rate parameters for the saturated area in $2012 / 13\left(k D O C_{\text {sat }}\right)$. Throughout, the activation energies $(E a)$, which were required to start DOC production, were broadly similar.

We also tested the model, by applying the retained parameter sets derived from the calibration to the 2012-2013 daily data set, to the weekly data from 2007 to 2009 data (Table 2). This was quite successful, with the consequent model performance actually being better for discharge $(\mathrm{KGE}=0.73)$, but poorer for DOC $(\mathrm{KGE}=0.55)$. Finally, we used the parameter sets derived from the model application to the 2007-2009 data (Birkel et al. 2014a) to the 2012-2013 data. This resulted in a poor performance for discharge (0.19), mainly as result of the snowmelt influence, which was not considered in the original analysis, though simulations of DOC remained reasonable $(0.59)$. 
Fig. 4 Measured (in blue) and modelled: a streamwater DOC loads; and $\mathbf{b}$ cumulative streamwater DOC loads. Modelled loads are broken down into the relative groundwater (black) and saturation overland flow (red) contributions to streamwater and the contributions of the hillslope to the saturated area (green). (Color figure online)

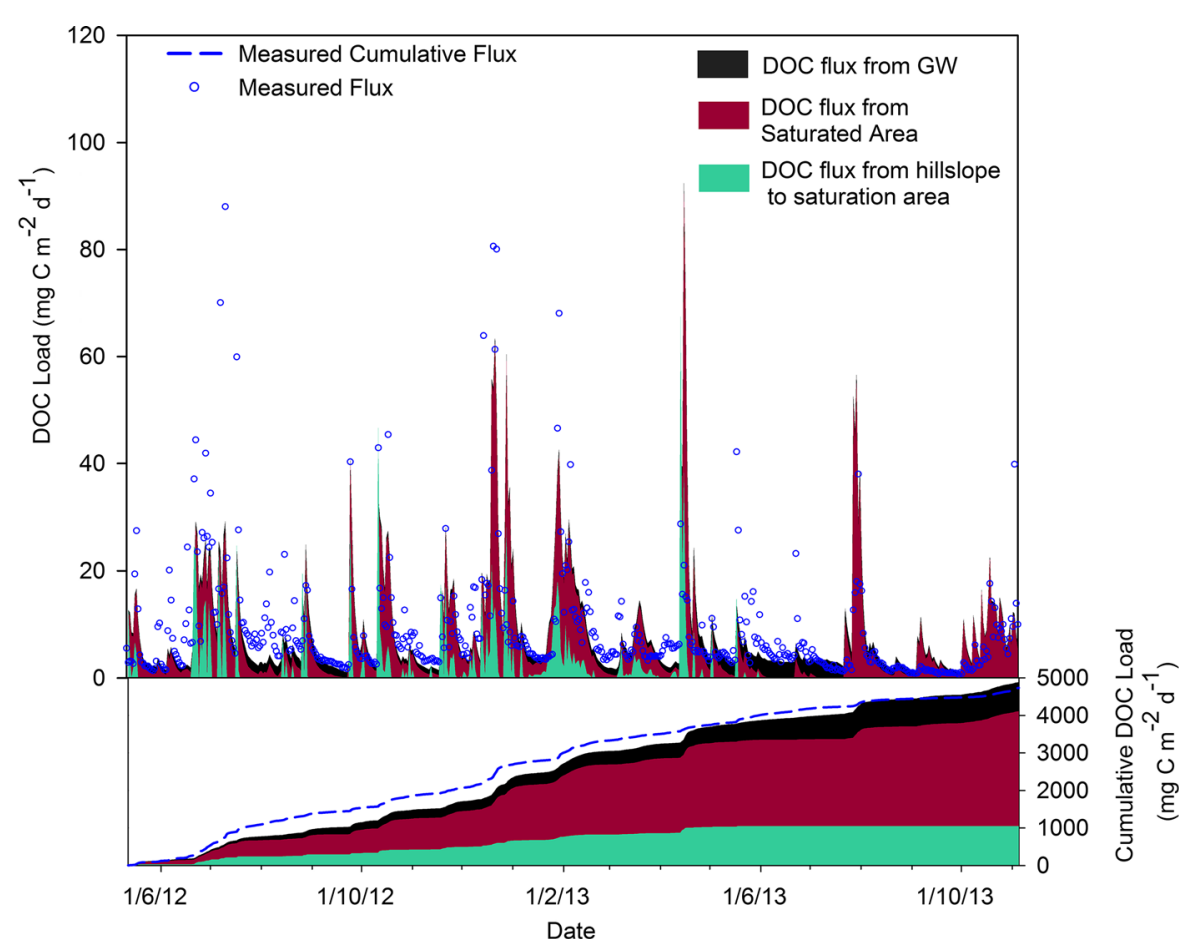

Simulated DOC fluxes from different landscape units

The model structure allowed us to disaggregate the daily DOC fluxes from the different model components, and to infer the contributions made by the individual landscape units (Fig. 4). Although DOC concentrations were higher in the summers, the higher winter flows produced larger DOC fluxes. DOC delivery from the riparian zone was by far the dominant contribution to the stream, in most events. The simulations show that only in the largest storm events were the hillslopes connected to the saturated area and delivered substantial fluxes into the riparian zone (Fig. 4a). In many smaller events, the riparian zone was the only unit increasing in hydrological and DOC flux. The groundwater flux remained low and fairly consistent throughout the study period, accounting for $16 \%$ of the total load. The modelled DOC loads tended to be underestimated, particularly during smaller events.

Total cumulative loads for simulated and observed data reached similar totals by the end of the study period (4.7 vs. $4.9 \mathrm{~g} \mathrm{C} \mathrm{m}^{-2} 18$ months $^{-1}$ respectively, Fig. 4b). The importance of the riparian saturation area became clear as a major contributor to stream DOC loads ( $84 \%$ of total load of which only $16 \%$ is DOC that has been derived from the hillslope areas). There was substantial interplay between flow and concentration depending on antecedent and prevailing hydro-meteorological conditions. The consistent GW inputs were smaller than the transient hillslope flux in 2012, but proportionally larger in the drier summer of 2013 when the hillslopes became disconnected (Fig. 5). There was no increase in hillslope cumulative loads during spring-summer 2013. Although the overall totals of modelled and measured loads were similar, periods of weaker model performance produced short-term deviations. Figure $4 \mathrm{~b}$ shows that in the wettest conditions, the simulated cumulative load tended to be underestimated. During the dry summer of 2013 the modelled load then exceeded the measured cumulative load.

\section{Discussion}

Coupled hydrological-biogeochemistry modelling

High concentrations of DOC are common in the surface waters of northern watersheds, where decomposition in histosols and other organic rich soils can generate 


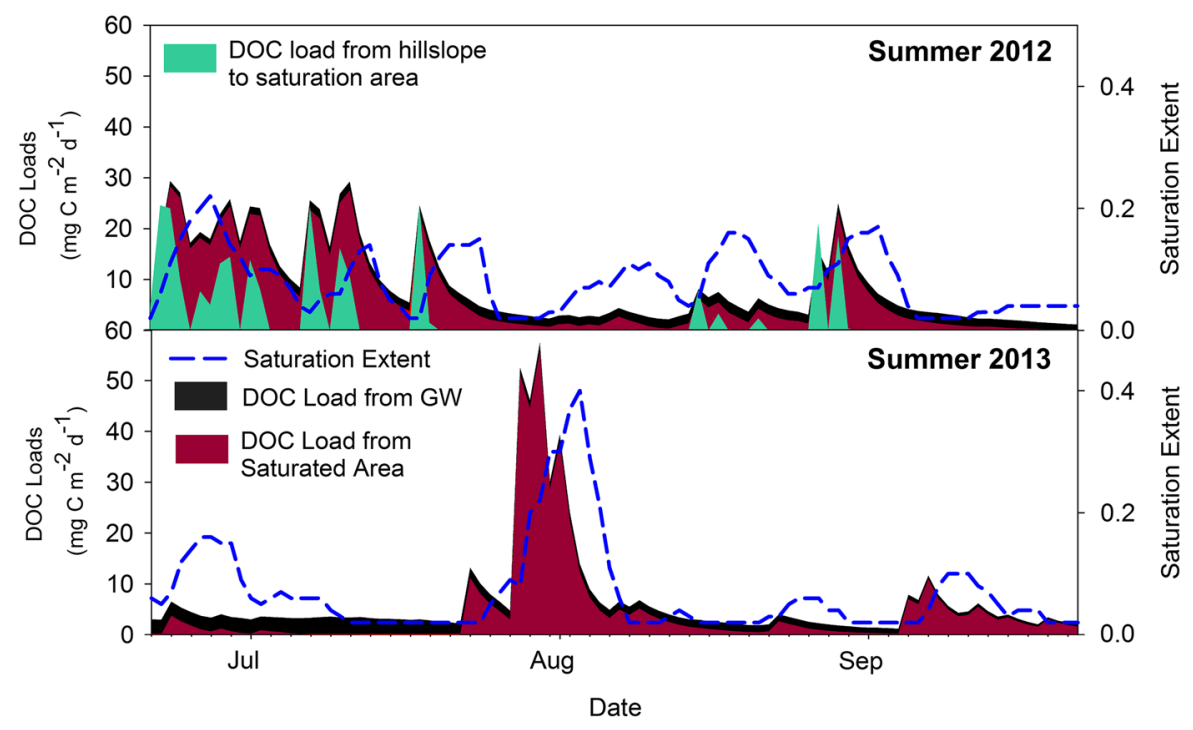

Fig. 5 Comparison of source area contributions to stream DOC loads during two summer seasons. Loads are broken down into the relative groundwater and saturation overland flow contributions

comparatively large quantities of carbon (Eimers et al. 2008). The dominance of near-surface hydrological flow paths in such soils results in episodic transport of DOC to streams during storm events, that is highly nonlinear (Buffam et al. 2007; Laudon et al. 2011; ̊̊gren et al. 2014; Tetzlaff 2014). In many areas, increasing DOC in surface waters has been reported and variously ascribed to the effects of reduced acid precipitation, changes in land management, climate change and increased drought frequency (Laudon et al. 2012). Given climate trajectories and increased land use change in northern regions, predictive models are needed to inform managers of potential water quality changes, including DOC from peat-covered catchments (Dillon and Molot 1997; Creed et al. 2003; Creed 2008). These approaches need to conceptualise the soil biogeochemical processes that generate DOC with hydrological transport mechanisms that connect sources to the stream network. Simple, identifiable models are advantageous, in this regard, as learning frameworks and they need to be able to simulate both longer term (i.e. seasonal and inter-annual) and episodic DOC dynamics.

The model used here was tested using a daily data set, collected over an 18 month period, with some remarkable climatic extremes, including the coolest, wettest winter for over 10 years (in 2012), the coldest spring for over 50 years and the warmest, driest to streamwater and the contributions of the hillslope to the saturated area. The saturation area extent as a fraction of total catchment area is also visualized. (Color figure online)

summer for over 10 years. Overall, the model calibrated simultaneously to hydrological and biogeochemical targets, performed satisfactorily, though this was only possible through the addition of a snowmelt component to the previous version of this model (Birkel et al. 2014a). The calibrated model performance, when tested and applied to simulate the 2007/09 weekly DOC time series, was also good. Previous work, using split model tests, had shown difficulties in transferring calibrated parameters between years, as individual years often had very different hydroclimatic characteristics (Birkel et al., 2014a). However, the 2012/13 period encompassed such variable conditions, which probably overcame some of these problems. In contrast, applications of the parameter sets derived from the model application to 2007/09, did not transfer well to $2012 / 13$, especially for flow. This largely reflects the lack of a snow routine in the warmer years of 2007-2009, where winter snow pack was negligible. Despite this, the overall DOC simulations were reasonable (cf. Table 2).

The results show the potential utility of simpler models, though the pros and cons associated with model complexity remain debateable. On the one hand, more complex models are likely to be more reliable at reproducing the controlling processes (McDonald and Urban 2010). Moreover, it has been argued that biogeochemical models, with lower 
parameterisation, may struggle to deal with the high degree of non-linear behaviour which is typical (Paudel and Jawitz 2012). On the other hand, the addition of complexity and parameters, does not guarantee improved model performance (e.g. Min, Paudel, and Jawitz 2011) and can increase uncertainty and equifinality (Beven 2012). Here, for example, the runoff model could have been improved by adding parameters, to better capture the response to smaller precipitation events, which the model struggled with. However, prior work by Birkel et al. (2014b) indicates that parameter identifiability would have been lost doing so and hence uncertainty increased. The coupled parsimonious models we have used here provide the basis for adequately modelling of the hydrologydependent nature of stream biogeochemistry, which captures the non-linear response of hydrological connection within transport processes that affect DOC, and the relative importance of different landscape units (Aufdenkampe et al. 2011). This moves us towards the goal of producing the correct results for the correct reason, with a much lower parameterized model than those usually used for DOC with similar measure of goodness-of-fit (Kirchner and James 2006). Whilst the site-specific nature of this study is recognised, the non-linear nature of hydrological dynamics in governing water quality is ubiquitous and the simple conceptualisation here has potential for wider applicability to other watersheds in northern regions and beyond.

Importance of different landscape units for DOC fluxes

A useful aspect of the model applied was that it allowed us to disaggregate the spatial distribution of DOC fluxes and assess the importance of different landscape units, as well as the non-linear nature of their contribution. In the Bruntland Burn, the saturated peat soils in the riparian zone are a critically important source area for DOC generation that accounts for around $84 \%$ of DOC delivery to streams. This importance of the riparian zone is in keeping with the findings of others (e.g. Billett et al. 2006; Winterdahl et al. 2011a). This is also consistent with the hydrological importance of these areas, identified in both empirical and modelling studies (Birkel et al. 2011a, b; Tetzlaff 2014). However, at larger scales beyond headwater catchments, the noticeable effects of riparian zones may decline, as these become masked by more heterogeneity in contributing water sources (Buffam et al. 2008). In contrast, groundwater provides a relatively small, stable source of DOC to streams, which is dominant only in the driest periods. These findings are similar to those of Tiwari et al. (2014), which showed the importance of changing hydrological flow paths and connectivity on stream water chemistry, with nearer surface flow paths dominating during wetter periods and deeper sources dominating during dry periods.

The most dynamic contribution comes from the larger hillslope areas of podzolic soils, which overall accounted for $16 \%$ of the total DOC exported from this system. For this zone, large DOC delivery is restricted to the wettest periods during high hydrological connection with the riparian wetlands, which lasts around 2-4 days depending upon the event size and antecedent conditions. In certain events (e.g. 15/08/12 and 27/08/12), the DOC contributions to the riparian wetlands may exceed the contribution of wetlands to the stream (Fig. 5). The dynamic nature of the hillslope fluxes is evident in the differences between the wet summer of 2012, with hillslope-riparian connectivity in most stream flow events, and the dry summer of 2013, when the hillslope remained disconnected for a long period, with only the riparian zone and groundwater contributing to stream DOC, similar to findings by McGlynn and McDonnell (2003).

\section{Conclusion}

A parsimonious coupled hydrological- biogeochemical model was utilised to source stream water DOC fluxes back to major landscape units. The simulations showed the critical importance of the riparian zone in contributing to total DOC fluxes (84\%) in wetland dominated peat catchments. The highly transient connectivity of the hillslope with the rest of the catchment was evident and largely dictated by antecedent wetness and event magnitude, leading to hillslope contributions only during wet periods and during events. The importance of hydrological connectivity was evident in the drier summer of 2013, during which the hillslope did not contribute to stream water DOC fluxes. In addition, the event based contributions of the saturated area declined, as streams reduced to summer base flows. The highly non-linear conditions during the study period (climate extremes 
existed throughout) produced a good basis for calibration of the data set. This study emphasises the importance of riparian zones in peat dominated catchments, with their large dynamic saturated areas. This is because they have the capacity to act as moderators of catchment hydrology, but also to act as biogeochemical hotspots within the landscape. Thus, the modelling approach presented here, has wider application to other peat dominated northern regions, and could also be adapted to address questions related to broader scale dynamics.

Acknowledgments We thank the Natural Environment Research Council NERC (project NE/K000268/1) for funding. Iain Malcolm and staff at Marine Scotland (Pitlochry) are also thanked for the provision of data from the AWS as are the Scottish Environmental Protection Agency and British Atmospheric Data Centre for the provision of meteorological data.

Open Access This article is distributed under the terms of the Creative Commons Attribution License which permits any use, distribution, and reproduction in any medium, provided the original author(s) and the source are credited.

\section{References}

Ågren AM, Buffam I, Cooper DM, Tiwari T, Evans CD, Laudon $\mathrm{H}$ (2014) Can the heterogeneity in stream dissolved organic carbon be explained by contributing landscape elements? Biogeosciences 11(4):1199-1213. doi:10.5194/bg-111199-2014

Asner GP, Townsend AR, Riley WJ, Matson PA, Neff JC, Cleveland CC (2001) Physical and biogeochemical controls over terrestrial ecosystem responses to nitrogen deposition. Biogeochemistry 54(1):1-39. doi:10.1023/A: 1010653913530

Aufdenkampe AK, Mayorga E, Raymond PA, Melack JM, Doney SC, Alin SR, Aalto RE, Yoo K (2011) Riverine coupling of biogeochemical cycles between land, oceans, and atmosphere. Front Ecol Environ 9(1):53-60

Band LE, Peterson DL, Running SW, Coughlan J, Lammers R, Dungan J, Nemani R (1991) Forest ecosystem processes at the watershed scale: basis for distributed simulation. Ecol Model 56:171-196. doi:10.1016/0304-3800(91)90199-B

Beven K (2012) Causal models as multiple working hypotheses about environmental processes. CR Geosci 344(2):77-88. doi:10.1016/j.crte.2012.01.005

Billett MF, Deacon CM, Palmer SM, Dawson JJ, Hope D (2006) Connecting organic carbon in stream water and soils in a peatland catchment. J Geophys Res: Biogeosciences 111(G2):G02010. doi:10.1029/2005JG000065

Birkel C, Tetzlaff D, Dunn SM, Soulsby C (2010) Towards a simple dynamic process conceptualization in rainfallrunoff models using multi-criteria calibration and tracers in temperate, upland catchments. Hydrol Process 24(3): 260-275. doi:10.1002/hyp.7478
Birkel C, Soulsby C, Tetzlaff D (2011a) Modelling catchmentscale water storage dynamics: reconciling dynamic storage with tracer-inferred passive storage. Hydrol Process 25(25):3924-3936. doi:10.1002/hyp.8201

Birkel C, Tetzlaff D, Dunn SM, Soulsby C (2011b) Using time domain and geographic source tracers to conceptualize streamflow generation processes in lumped rainfall-runoff models. Water Resour Res 47 doi: 201110.1029/2010WR 009547

Birkel C, Tetzlaff D, Soulsby C. (2014)a Integrating parsimonious models of hydrological connectivity and soil biogeochemistry to simulate stream doc dynamics J Geophys Res: Biogeosciences, doi: 10.1002/2013JG002551

Birkel C, Tetzlaff D, Soulsby C (2014b) Developing a consistent process-based conceptualization of catchment functioning using measurements of internal state variables. Water Resour Res. doi:10.1002/2013WR014925

Boyer EW, Hornberger GM, Bencala KE, McKnight D (1996) Overview of a simple model describing variation of dissolved organic carbon in an upland catchment. Ecol Model 86(2-3):183-188. doi:10.1016/0304-3800(95)00049-6

Buffam I, Laudon H, Temnerud J, Mörth CM, Bishop K (2007) Landscape-scale variability of acidity and dissolved organic carbon during spring flood in a boreal stream network. J Geophys Res: Biogeosciences 112 (G1) doi: 10. 1029/2006JG000218

Buffam I, Laudon H, Seibert J, Mörth CM, Bishop K (2008) Spatial heterogeneity of the spring flood acid pulse in a boreal stream network. Sci Total Environ 407(1):708-722. doi:10.1016/j.scitotenv.2008.10.006

Capell R, Tetzlaff D, Malcolm IA, Hartley AJ, Soulsby C (2011) Using hydrochemical tracers to conceptualise hydrological function in a larger scale catchment draining contrasting geologic provinces. J Hydrol 408(1-2):164-177. doi:10. 1016/j.jhydrol.2011.07.034

Creed IF, Sanford SE, Beall FD, Molot LA, Dillon PJ (2003) Cryptic wetlands: integrating hidden wetlands in regression models of the export of dissolved organic carbon from forested landscapes. Hydrol Process 17(18):3629-3648. doi:10.1002/hyp. 1357

Creed IF, Beall FD, Clair TA, Dillon PJ, Hesslein RH (2008) Predicting export of dissolved organic carbon from forested catchments in glaciated landscapes with shallow soils. Glob Biogeochem Cycles 22(4) doi: 10.1029/ 2008GB003294

Dawson JJC, Soulsby C, Tetzlaff D, Hrachowitz M, Dunn SM, Malcolm IA (2008) Influence of hydrology and seasonality on DOC exports from three contrasting upland catchments. Biogeochemistry 90(1):93-113

Dawson JJC, Tetzlaff D, Speed M, Hrachowitz M, Soulsby C (2011) Do multiple sources and attenuated hydrology lead to convergent DOC fluxes in larger catchments? Hydrol Process. doi:10.1002/hyp.7925

Deb K, Pratap A, Agarwal S, Meyarivan T (2002) A fast and elitist multiobjective genetic algorithm: NSGA-II. IEEE Trans Evol Comput 6(2):182-197. doi:10.1109/4235. 996017

Dillon PJ, Molot LA (1997) Effect of landscape form on export of dissolved organic carbon, iron, and phosphorus from forested stream catchments. Water Resour Res 33(11):2591-2600. doi:10.1029/97WR01921 
Dunn SM, Mackay R (1995) Spatial variation in evapotranspiration and the influence of land use on catchment hydrology. J Hydrol 171(1-2):49-73. doi:10.1016/00221694(95)02733-6

Eimers MC, Buttle J, Watmough SA (2008) Influence of seasonal changes in runoff and extreme events on dissolved organic carbon trends in wetland- and upland-draining streams. Can J Fish Aquat Sci 65(5):796-808. doi:10.1139/ f07-194

Futter MN, Butterfield D, Cosby BJ, Dillon PJ, Wade AJ, Whitehead PG (2007) Modeling the mechanisms that control in-stream dissolved organic carbon dynamics in upland and forested catchments. Water Resour Res doi: 200710.1029/2006WR004960

Futter MN, Starr M, Forsius M, Holmberg M et al (2008) Modelling the effects of climate on long-term patterns of dissolved organic carbon concentrations in the surface waters of a boreal catchment. Hydrol Earth Syst Sci 12(2):437-447

Futter MN, Erlandsson MA, Butterfield D, Whitehead PG, Oni SK, Wade AJ (2014) PERSiST: a flexible rainfall-runoff modelling toolkit for use with the INCA family of models. Hydrol Earth Syst Sci 18(2):855-873. doi:10.5194/hess18-855-2014

Gupta HV, Kling H, Yilmaz KK, Martinez GF (2009) Decomposition of the mean squared error and NSE performance criteria: implications for improving hydrological modelling. J Hydrol 377(1-2):80-91. doi:10.1016/j.jhydrol.2009. 08.003

Halbedel S, Büttner O, Weitere M (2013) Linkage between the temporal and spatial variability of dissolved organic matter and whole-stream metabolism. Biogeosciences 10(8): 5555-5569. doi:10.5194/bg-10-5555-2013

Hope D, Billett MF, Cresser MS (1994) A review of the export of carbon in river water: fluxes and processes. Environ Pollut 84(3):301-324. doi:10.1016/0269-7491(94)90142-2

Inamdar SP, Mitchell MJ (2006) Hydrologic and topographic controls on storm-event exports of dissolved organic carbon (doc) and nitrate across catchment scales. Water Resour Res 42(3):W03421

Karanfil T, Krasner SW, Westerhoff P, Xie Y (2008) Recent advances in disinfection by-product formation, occurrence, control, health effects, and regulations. Disinfection ByProducts in Drinking Water, 995:2-19. American Chemical Society. doi: 10.1021/bk-2008-0995.ch001

Kirchner JW (2006) Getting the right answers for the right reasons: linking measurements, analyses, and models to advance the science of hydrology. Water Resour Res 42(3):W03S04 doi: 10.1029/2005WR004362

Kling H, Fuchs M, Paulin M (2012) Runoff conditions in the upper danube basin under an ensemble of climate change scenarios. J Hydrol 424-425(March):264-277. doi:10. 1016/j.jhydrol.2012.01.011

Laudon H, Berggren M, Ågren A, Buffam I, Bishop K, Grabs T, Jansson M, Köhler S (2011) Patterns and dynamics of dissolved organic carbon (DOC) in boreal streams: the role of processes, connectivity, and scaling. Ecosystems 14(6):880-893. doi:10.1007/s10021-011-9452-8

Laudon H, Buttle J, Carey SK, McDonnell J, McGuire K, Seibert J, Shanley J, Soulsby C, Tetzlaff D (2012) Crossregional prediction of long-term trajectory of stream water
DOC response to climate change. Geophys Res Lett 39(18):L18404. doi:10.1029/2012GL053033

Ledesma JLJ, Köhler SJ, Futter MN (2012) Long-term dynamics of dissolved organic carbon: implications for drinking water supply. Sci Total Environ 432:1-11

Malcolm IA, Soulsby C, Youngson AF, Tetzlaff D (2008) Fine scale variability of hyporheic hydrochemistry in salmon spawning gravels with contrasting groundwater-surface water interactions. Hydrogeol J 17(July):161-174. doi:10. 1007/s10040-008-0339-5

McDonald CP, Urban NR (2010) Using a model selection criterion to identify appropriate complexity in aquatic biogeochemical models. Ecol Model 221(3):428-432. doi:10. 1016/j.ecolmodel.2009.10.021

McGlynn BL, McDonnell JJ (2003) Role of discrete landscape units in controlling catchment dissolved organic carbon dynamics. Water Resour Res 39(4):1090. doi:10.1029/ 2002WR001525

Michalzik B, Tipping E, Mulder J, Gallardo Lancho JF, Matzner E, Bryant CL, Clarke N, Lofts S, Vicente Esteban MA (2003) Modelling the production and transport of dissolved organic carbon in forest soils. Biogeochemistry 66(3):241-264. doi:10.1023/B:BIOG.0000005329.68861.27

Min JH, Paudel R, Jawitz JW (2011) Mechanistic biogeochemical model applications for Everglades restoration: a review of case studies and suggestions for future modeling needs. Crit Rev Environ Sci Technol 41(sup1):489-516. doi:10.1080/10643389.2010.531227

Neal C, Reynolds B, Kirchner JW, Rowland P, Norris D, Sleep D, Lawlor A et al (2013) High-frequency precipitation and stream water quality time series from Plynlimon, Wales: an openly accessible data resource spanning the periodic table. Hydrol Process 27(17):2531-2539. doi:10.1002/hyp.9814

Neff JC, Asner GP (2001) Dissolved organic carbon in terrestrial ecosystems: synthesis and a model. Ecosystems 4(1):29-48. doi:10.1007/s100210000058

Oni SK, Futter MN, Teutschbein C, Laudon H (2014) Crossscale ensemble projections of dissolved organic carbon dynamics in boreal forest streams. Clim Dyn 42(9-10):2305-2321. doi:10.1007/s00382-014-2124-6

Paudel R, Jawitz JW (2012) Does increased model complexity improve description of phosphorus dynamics in a large treatment wetland? Ecol Eng 42(May):283-294. doi:10. 1016/j.ecoleng.2012.02.014

Pellerin BA, Saraceno JF, Shanley JB, Sebestyen SD, Aiken GR, Wollheim WM, Bergamaschi BA (2012) Taking the pulse of snowmelt: in situ sensors reveal seasonal, event and diurnal patterns of nitrate and dissolved organic matter variability in an upland forest stream. Biogeochemistry 108(1-3):183-198

Peterson FS, Lajtha KJ (2013) Linking aboveground net primary productivity to soil carbon and dissolved organic carbon in complex terrain. J Geophys Res: Biogeosciences 118(3):1225-1236

Roulet N, Moore TR (2006) Environmental chemistry: browning the waters. Nature 444(7117):283-284. doi:10.1038/ 444283a

Seibert J, Grabs T, Koehler S, Laudon H, Winterdahl M, Bishop K (2009) Linking soil- and stream-water chemistry based on a riparian flow-concentration integration model. Hydrol Earth Syst Sci 13(12):2287-2297 
Tank JL, Rosi-Marshall EJ, Griffiths NA, Entrekin SA, Stephen ML (2010) A review of allochthonous organic matter dynamics and metabolism in streams. J N Am Benthol Soc 29(1):118-146. doi:10.1899/08-170.1

Tetzlaff D, Soulsby C, Waldron S, Malcolm IA, Bacon PJ, Dunn SM, Lilly A, Youngson AF (2007) Conceptualization of runoff processes using a geographical information system and tracers in a nested mesoscale catchment. Hydrol Process 21(10):1289-1307

Tetzlaff D, Birkel C, Dick J, Geris J, Soulsby C (2014) Storage dynamics in hydropedological units control hillslope connectivity, runoff generation and the evolution of catchment transit time distributions. Water Resour Res doi: 10.1002/ 2013WR014147
Tiwari T, Laudon H, Beven K, Ågren AM (2014) Downstream changes in DOC: inferring contributions in the face of model uncertainties. Water Resour Res 50(1):514-525. doi:10.1002/2013WR014275

Winterdahl M, Temnerud J, Futter MN, Löfgren S, Moldan F, Bishop K (2011a) Riparian zone influence on stream water dissolved organic carbon concentrations at the Swedish integrated monitoring sites. Ambio 40(8):920-930

Winterdahl M, Futter M, Köhler S, Laudon H, Seibert J, Bishop K (2011b) Riparian soil temperature modification of the relationship between flow and dissolved organic carbon concentration in a boreal stream. Water Resour Res 47(8):W08532. doi:10.1029/2010WR010235 